\title{
Adenocarcinoma of the esophagus
}

\author{
INSERM
}

\section{Source}

INSERM. (1999). Orphanet: an online rare disease and orphan drug data base.

Adenocarcinoma of the esophagus. ORPHA:99976

Esophageal adenocarcinoma (EAC) is a sub-type of esophageal carcinoma (EC; see this term) affecting the glandular cells of the lower esophagus at the junction with the stomach. 